Journal of Agricultural Sciences
(Tarim Bilimleri Dergisi)

\title{
Five new records of eriophyid mites (Acari: Eriophyoidea) from herbaceous plants and fruit trees in Van province, Turkey
}

\author{
Evsel DENİZHAN ${ }^{\mathrm{D}}$, Sultan ÇOBANOĞLU ${ }^{\mathrm{b} *}$ (D) İbrahim ÇAKMAK ${ }^{\mathrm{C}} \mathbb{D}$ \\ ${ }^{a}$ Trakya University, Faculty of Science, Department of Biology, Edirne, TURKEY

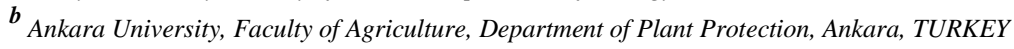

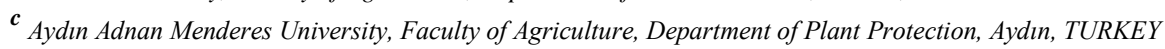

\section{ARTICLE INFO}

Research Article

Corresponding Author: Sultan ÇOBANOĞLU, E-mail: scobanoglu@ankara.edu.tr, coban.sultan@gmail.com

Received: 05 December 2020 / Revised: 25 February 2021 / Accepted: 26 February 2021 / Online: 20 January 2022

\section{ABSTRACT}

Five species of eriophyoid mites were detected as new records for the mite fauna of Turkey. The samples were collected on herbaceous plants and fruit trees in Bahçesaray, Edremit, İskele and Akdamar island of Van province, Turkey between 2014 and 2016. The identified eriophyid species are Aceria camdeboo (Meyer, 1981) on Celtis sp. (Cannabaceae); A. trifolii (Nalepa, 1892) on Vicia biennis L. (Fabaceae), Aculus parakarensis (Bagdasarian, 1972) on Amygdalus communis L. (Rosaceae), Leipothrix moraceus (Castagnoli, 1980) on Morus alba L. (Moraceae) and Phyllocoptes obtusus (Nalepa, 1891) on Salvia sp. (Lamiaceae). The species are depicted, measured and information on their hosts, damage symptoms and geographical distribution are given.

Keywords: Eriophyoidea, New record, Aceria, Van, Turkey

(C) Ankara University, Faculty of Agriculture

\section{Introduction}

Eriophyoid mites are very small, obligatory phytophagous invertebrates and the majority of these mites are host specific (Lindquist et al. 1996). Weed-associated eriophyoids are considered to have high potential as biological control agents because of their host specificity (Smith et al. 2010). Turkey has a rich eriophyoid biodiversity because of the geographical position and botanical history of the country (Ekim \& Güner 2000; Karagöz 2003). Many studies were carried out to determine the eriophyoid fauna of Turkey (Denizhan et al. 2006, 2008; Denizhan \& Çobanoğlu 2010). Denizhan et al. (2015) listed eriophyoid mites in a catalogue along with remarks and information on their current distribution in Turkey and they reported that a total of 130 eriophyoid species for the Turkish fauna up to March 2013. Then, eight eriophyoid species were determined as new records for Turkey: Aceria tenuis (Nalepa 1891), Epitrimerus gibbosus (Nalepa 1892) and Quadracus urticae (Keifer 1944) on weed plants in Samsun (Diler \& Ozman-Sullivan 2011), Aceria sobhiani Sukhareva, 2001 on Acroptilon repens L., Aceria carduui Petanovic, Boczek and Shi 2002 on Carduus pycnocephalus L. in Ankara (Diler \& Ozman-Sullivan 2016), Aceria stefanii (Nalepa 1898) on pistachio trees in the South-Eastern Anatolia (Usanmaz et al. 2018), Aceria diospyri (Keifer 1944) on Diospyros kaki L. in Yalova (Denizhan 2018) and Rhyncaphytoptus castaneae (Farkas 1960) on Castanea sativa Mill. in Aydin (Gokce et al. 2020).

Although only 138 eriophyoid mite species have been recorded in Turkey to date, there is still many more to be discovered. Therefore, the aim of this study is to add five new species from Van region in Turkey. These new records, increased the total number of eriophyoid species to 143 in Turkey.

\section{Material and Methods}

The plant samples were collected from herbaceous plants and fruit trees in Bahçesaray, Edremit, İskele and Akdamar island of Van province, located in the Eastern part of Turkey, between 2014 and 2016. Eriophyid mites collected from the plants were directly examined under a dissecting stereo-microscope (Leica ES2) and mounted on microscope slides in F-medium according to Keifer (1975). The identifications were made with the help of a phase-contrast microscope (Leica DM 1000). The morphological nomenclature follows Lindquist et al. (1996), all the measurements were made according to Amrine \& Manson (1996) and De Lillo et al. (2010). The systematic classification follows Amrine et al. (2003). Information on the hosts and damage symptoms, geographical distribution of these species and GPS coordinates of the location of each sample are provided. The Prodorsal shield, empodium and genital area are figured. The voucher specimens of the species are kept in the mite collection of the Faculty of Science, University of Trakya, Edirne, Turkey. 


\section{Results and Discussion}

Five eriophyoid mites were identified as new records for the mite fauna of Turkey from herbaceous plants and fruit trees in Van province: Aceria camdeboo (Meyer, 1981), A. trifolii (Nalepa, 1892), Aculus parakarensis (Bagdasarian, 1972), Leipothrix moraceus (Castagnoli, 1980) and Phyllocoptes obtusus (Nalepa, 1891). Information on the measurements, drawings, hosts, damage symptoms and geographical distribution of these species are given below.

\section{Family: Eriophyidae Nalepa, 1898}

Subfamily: Eriophyinae Nalepa, 1898

Genus: Aceria Keifer, 1944

Aceria camdeboo (Meyer, 1981)

Female: 188-217 $\mu \mathrm{m}$ long, 43-54 $\mu \mathrm{m}$ wide; gnathosoma 9-12 $\mu \mathrm{m}$ long; gnathosomal setae 3-4; chelicerae 10-11 $\mu \mathrm{m}$; Prodorsal shield 20-22 $\mu \mathrm{m}$ long, 30-31 $\mu \mathrm{m}$ wide; dorsal setae 11-13 $\mu \mathrm{m}$ long (Figure 1a).

Leg: Foreleg $18 \mu \mathrm{m}$ long; tibia $4 \mu \mathrm{m}$; tarsus $5 \mu \mathrm{m}$; tarsal solenidion $7 \mu \mathrm{m}$; empodium $5 \mu \mathrm{m}$ long; empodium 3 rayed (Figure 1c). Hindleg $19 \mu \mathrm{m}$ long; tibia $4 \mu \mathrm{m}$; tarsus $5 \mu \mathrm{m}$; tarsal solenidion $7 \mu \mathrm{m}$; empodium $5 \mu \mathrm{m}$ long; empodium 3 rayed.

Genitalia $10 \mu \mathrm{m}$ long; $13 \mu \mathrm{m}$ wide; female genital cover flap smooth; genital setae $10 \mu \mathrm{m}$ (Figure $1 \mathrm{~b}$ ).

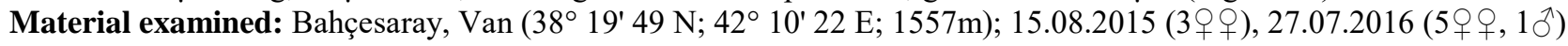

Host Plant: Celtis sp. (Cannabaceae)

Geographical distribution: South Africa (Amrine \& Stasny, 1994) and Turkey (present study)

Remarks: We observed that the mite produces bead-like galls. Twelve species of eriophyoid were found on the Celtis. Since Aceria species are not detected on Celtis spp. in the Palearctic region (Amrine \& Stasny, 1994), A. camdeboo is also a new record for the Palearctic region.

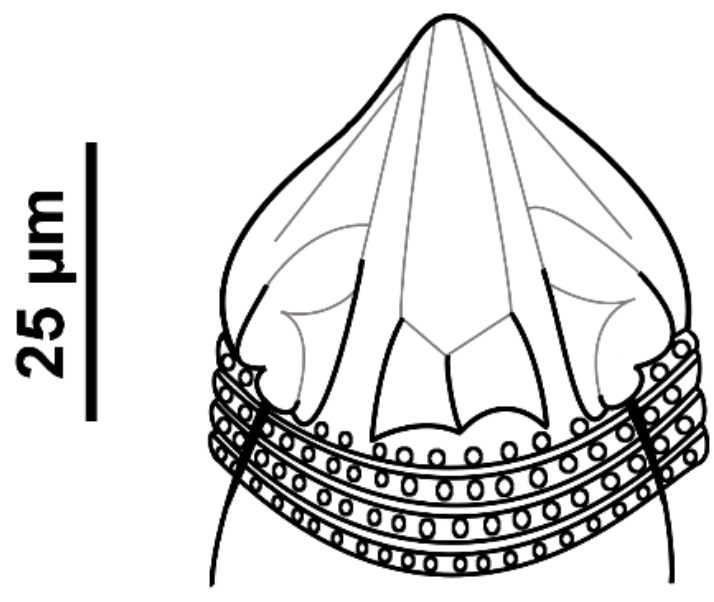

a

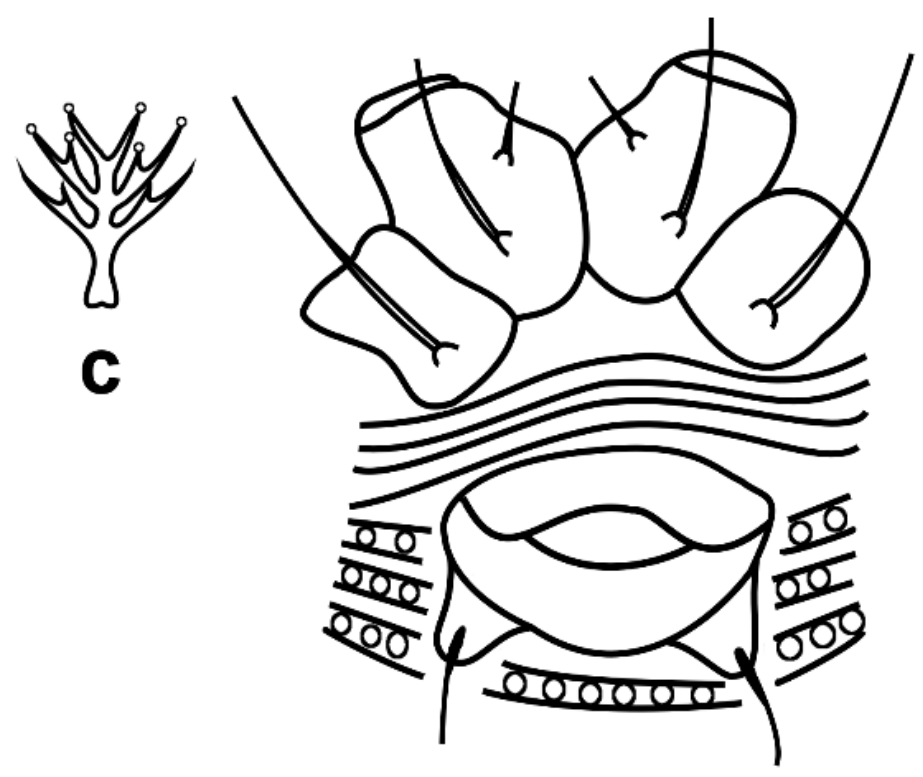

b

Figure 1- Aceria camdeboo a- Prodorsal shield, b- Genitalia, c- Empodium

\section{Aceria trifolii (Nalepa, 1892)}

Synonym: Eriophyes plicator var. trifolii (Nalepa, 1892)

Female: 149-200 $\mu \mathrm{m}$ long, 56-60 $\mathrm{m}$ wide; gnathosoma 9-11 $\mu \mathrm{m}$ long; gnathosomal setae 3-5; chelicerae 6-10 $\mu \mathrm{m}$; Prodorsal shield 33-35 $\mu \mathrm{m}$ long, 32-37 $\mu \mathrm{m}$ wide; dorsal setae 10-17 $\mu \mathrm{m}$ long (Figure 2a).

Leg I. 26-35 $\mu \mathrm{m}$ long; tibia 5-6 $\mu \mathrm{m}$; Tarsus 5-7 $\mu \mathrm{m}$; tarsal solenidion 7-8 $\mu \mathrm{m}$; empodium 5-6 $\mu \mathrm{m}$ long; empodium 5 rayed. Leg II. 27-32 $\mu \mathrm{m}$ long; tibia 5-7 $\mu \mathrm{m}$; tarsus 5-7 $\mu \mathrm{m}$; tarsal solenidion 7-8 $\mu \mathrm{m}$; empodium 5-6 $\mu \mathrm{m}$ long; empodium 5 rayed. 
Genitalia 10-13 $\mu \mathrm{m}$ long; 17-28 $\mu \mathrm{m}$ wide; female genital cover flap ( 8 ridges); genital setae 12-19 $\mu \mathrm{m}$ (Figure 2b).

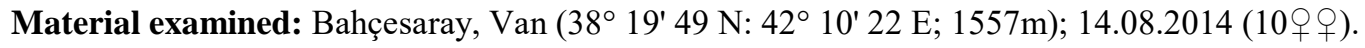

Host Plant: Vicia biennis L. (Fabaceae)

Geographical distribution: Bosnia, France, Germany, Hungary, Italy and Turkey (present study).

Remarks: We observed that the mite caused leaf curling and bleaching. The mite was originally reported on Trifolium arvense L. and then Medicago falcata L., M. lupulina L., Ononis minutissima L., Trifolium dubium Sibth., T. pratense Sibth., P. repens L., Vicia hirsuta L. in the Palearctic region, and caused proliferation of flowers and deformation of leaves. Vicia biennis is recorded as a new host plant for A. trifolii in this study. The lengths of opisthosoma, gnathosoma and prodorsal shield, which are important features for species identification, of the Turkish specimens of Aceria trifolii differs slightly in the Turkish specimens from that of the type specimens. The lengths of opisthosoma and gnathosoma are longer in the Turkish specimens, $200 \mu \mathrm{m}$ and $11 \mu \mathrm{m}$ but $190 \mu \mathrm{m}$ and $9 \mu \mathrm{m}$ in the type specimens. The length of prodorsal shield in the Turkish specimens $(35 \mu \mathrm{m})$ is narrower than in the type specimens $(38 \mu \mathrm{m})$.

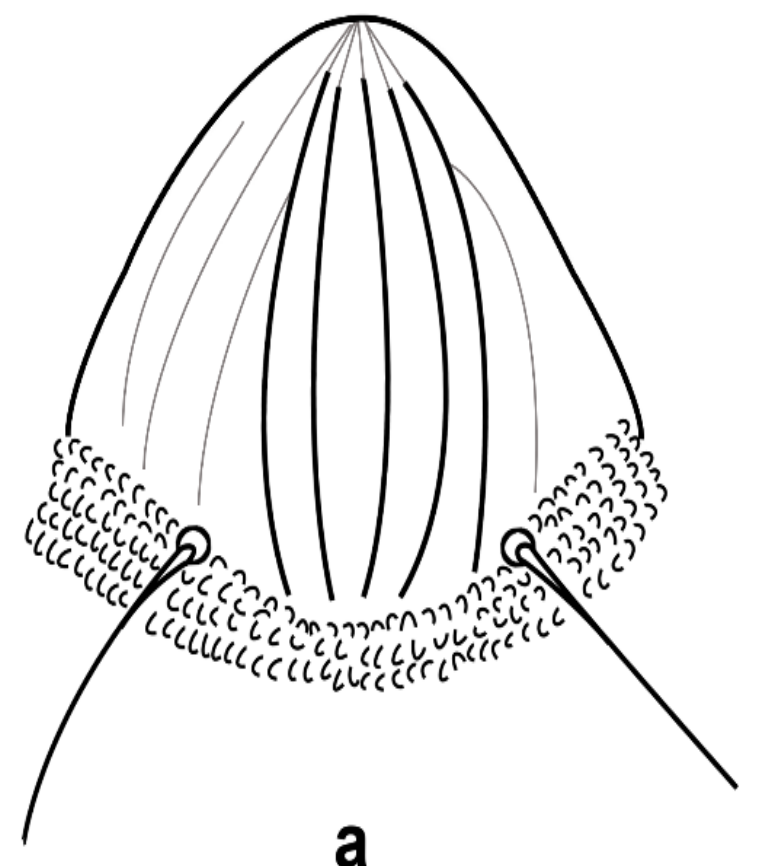

a

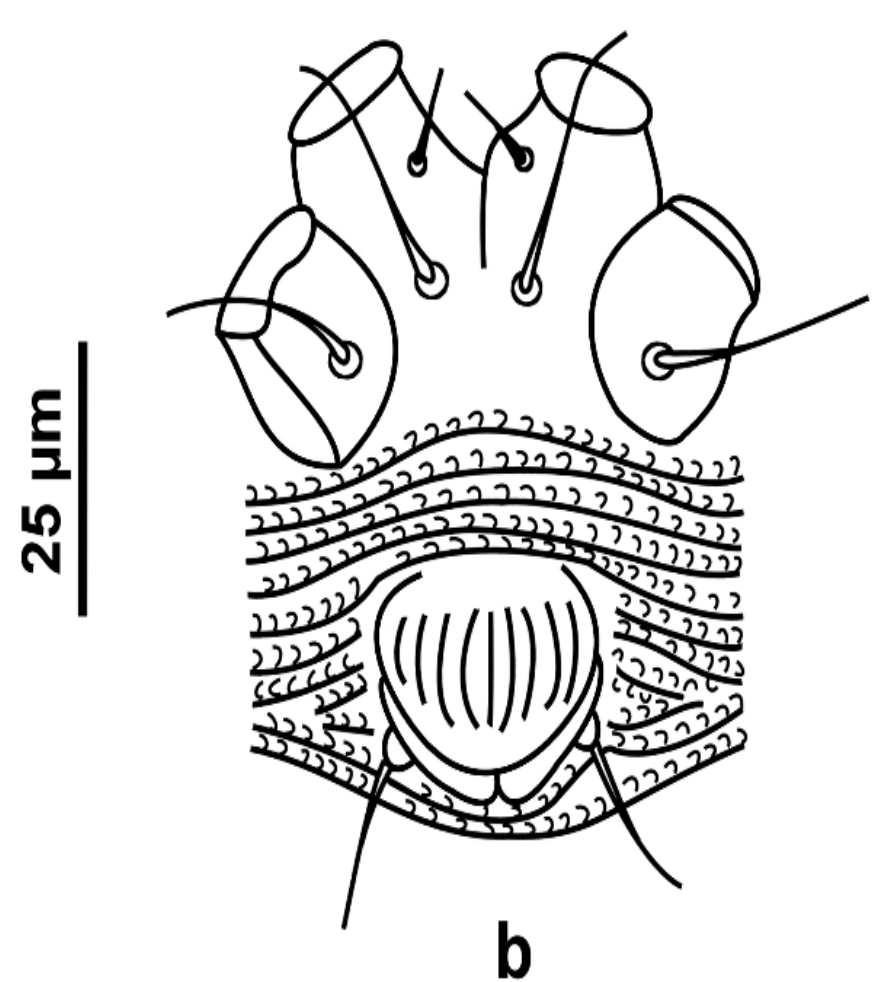

b

Figure 2- Aceria trifolii (Nalepa, 1892) a. Prodorsal shield, b. Genitalia

\author{
Subfamily: Phyllocoptinae \\ Tribus: Anthocoptini \\ Genus: Aculus Keifer, 1959 \\ Aculus parakarensis (Bagdasarian, 1972)
}

Female: 149-158 $\mu \mathrm{m}$ long, 45-51 $\mu \mathrm{m}$ wide; gnathosoma 17-21 $\mu \mathrm{m}$ long; gnathosomal setae 2-3; Prodorsal shield smooth, 23-26 $\mu \mathrm{m}$ long, 29-33 $\mu \mathrm{m}$ wide, dorsal setae 10-14 $\mu \mathrm{m}$ long (Figure 3a).

Leg I. 24 -26 $\mu \mathrm{m}$ long; tibia 5-6 $\mu \mathrm{m}$; tarsus 6-7 $\mu \mathrm{m}$; empodium 8-9 $\mu \mathrm{m}$ long; empodium 5 rayed. Leg II. 22-24 $\mu \mathrm{m}$ long; tibia 4-5 $\mu \mathrm{m}$; tarsus 5-7 $\mu \mathrm{m}$; empodium 8-9 $\mu \mathrm{m}$ long; empodium 5 rayed (Figure 3c). Genitalia 11-14 $\mu \mathrm{m}$ long; 18-20 $\mu \mathrm{m}$ wide; female genital flap smooth; genital setae 11-14 $\mu \mathrm{m}$ (Figure 3b). 


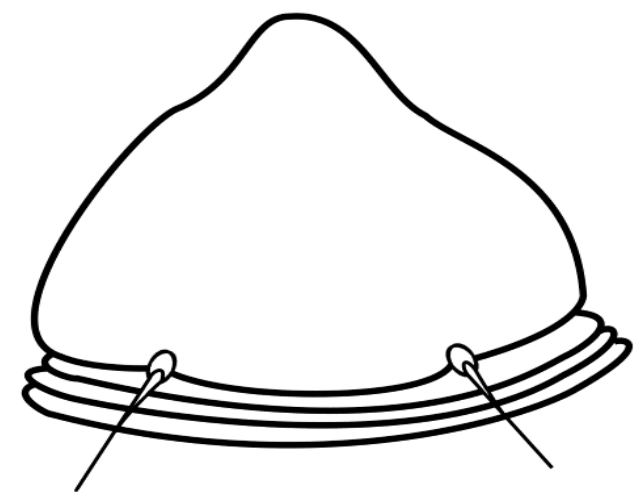

a

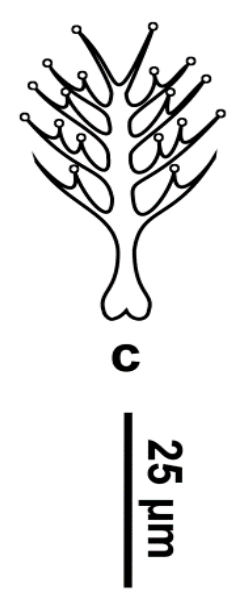

今

둥

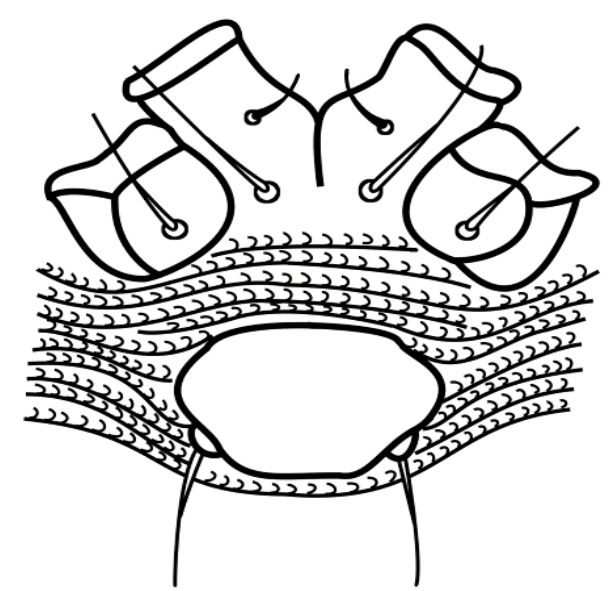

b

Figure 3- Aculus parakarensis (Bagdasarian, 1972) a- Prodorsal shield, b- Genitalia, c- Empodium

Material examined: Akdamar island, Van (382 $\left.24^{\prime} 04 \mathrm{~N} ; 43^{\circ} 14^{\prime} 12 \mathrm{E} ; 1802 \mathrm{~m}\right) ; 21.08 .2014$ (7 우).

Host plants: Amygalus communis L. (Rosaceae)

Geographical distribution: Armenia, Bulgaria, Hungary (Amrine et al. 2003) and Turkey (present study).

Remarks: This species is a vagrant on the undersurface of leaves without causing apparent damage. Aculus parakarensis has only been found in the Palearctic region so far, and its widespread host is Amygalus communis (Ripka, 2007).

\section{Genus: Leipothrix Keifer, 1966}

Leipothrix moraceus (Castagnoli, 1980)

Female: $160-230 \mu \mathrm{m}$ long, 59-63 $\mu \mathrm{m}$ wide; gnathosoma 7-8 $\mu \mathrm{m}$ long; gnathosomal setae 6-7; chelicerae 6-11 $\mu \mathrm{m}$; Prodorsal shield 48-50 $\mu \mathrm{m}$ long; 53-55 $\mu \mathrm{m}$ wide; dorsal setae 11-18 $\mu \mathrm{m}$ long (Figure 4a).

Leg I. 33-36 $\mu \mathrm{m}$ long; tibia 5-6 $\mu \mathrm{m}$; tarsus 4-5 $\mu \mathrm{m}$; tarsal solenidion 4-5 $\mu \mathrm{m}$; empodium 5-6 $\mu \mathrm{m}$ long; empodium 4 rayed. Leg II. 41-43 $\mu \mathrm{m}$ long; tibia 5-6 $\mu \mathrm{m}$; tarsus 4-5 $\mu \mathrm{m}$; tarsal solenidion 5-6 $\mu \mathrm{m}$; empodium 5-6 $\mu \mathrm{m}$ long; empodium 4 rayed.

Genitalia 11-12 $\mu \mathrm{m}$ long; 20-22 $\mu \mathrm{m}$ wide; female genital flap smooth; genital setae 14-16 $\mu \mathrm{m}$ (Figure 4b).

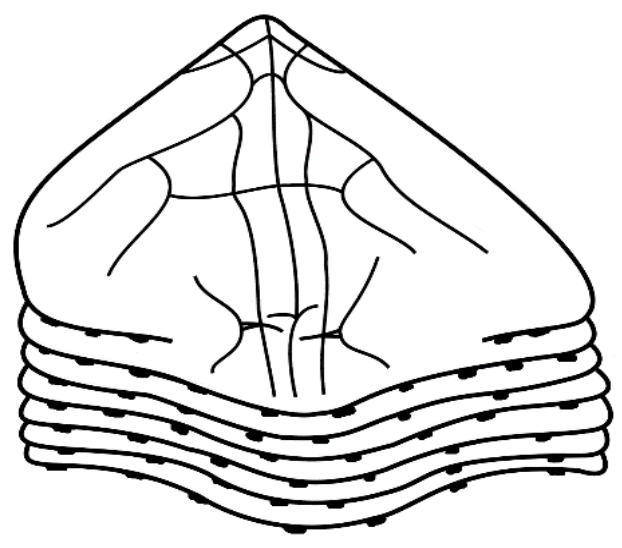

a

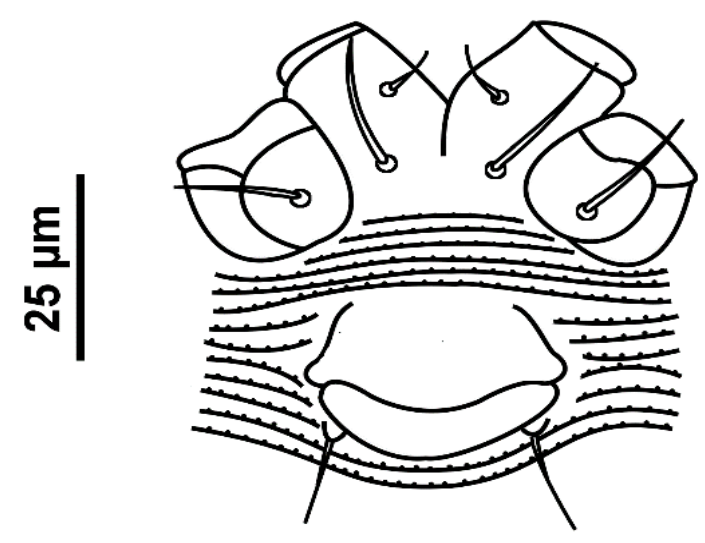

b

Figure 4- Leipothrix moraceus (Castagnoli, 1980) a- Prodorsal shield, b- Genitalia

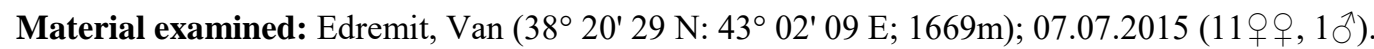

Host Plant: Morus alba L. (Moraceae)

Geographical distribution: Italy (Castagnoli, 1980), China (Wang et al. 2017) and Turkey (present study).

Remarks: This species was previously found in Palearctic and Oriental regions (Amrine \& Stasny, 1994). We observed that this species caused rust of leaves. The lengths of the body, prodorsal shield and tibia of the Turkish specimens of Leipothrix moraceus differs from that of the type specimens as follows: body length in the Turkish specimens $(230 \mu \mathrm{m})$ is longer than in the Italian specimens $(215 \mu \mathrm{m})$; length of prodorsal shield is also longer in the Turkish specimens $(53 \mu \mathrm{m})$ than Italian specimens $(50 \mu \mathrm{m})$ and the tibia in the Turkish specimens $(6 \mu \mathrm{m})$ is slightly shorter than the that of the Italian specimens $(8 \mu \mathrm{m})$. 
Genus: Phyllocoptes Nalepa, 1887

Phyllocoptes obtusus (Nalepa, 1891)

Female: $150 \mu \mathrm{m}$ long, $45 \mu \mathrm{m}$ wide; gnathosoma 20-22 $\mu \mathrm{m}$ long; gnathosomal setae 2-3; chelicerae 12-18 $\mu \mathrm{m}$; Prodorsal shield 38-40 $\mu \mathrm{m}$ long;11-13 $\mu \mathrm{m}$ wide; dorsal setae14-17 $\mu \mathrm{m}$ long (Figure 5a);

Leg I. 28-33 $\mu \mathrm{m}$ long; tibia 5-6 $\mu \mathrm{m}$; Tarsus 5-6 $\mu \mathrm{m}$; empodium $7 \mu \mathrm{m}$ long; empodium 4 rayed. Leg II. 35-36 $\mu \mathrm{m}$ long; tibia 5-7 $\mu \mathrm{m}$; tarsus 6-7 $\mu \mathrm{m}$; empodium 6-7 $\mu \mathrm{m}$ long; empodium 4 rayed.

Genitalia 11-15 $\mu \mathrm{m}$ long; 22-29 $\mu \mathrm{m}$ wide; genital seta 18-20 $\mu \mathrm{m}$ (Figure 5b); female genital cover flap (9 ridges).

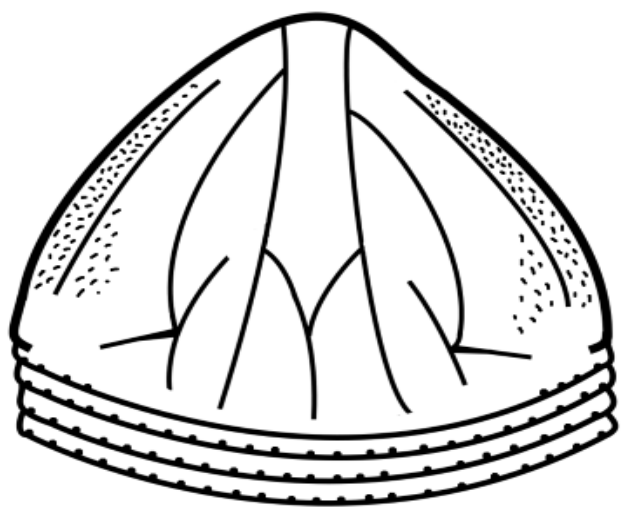

a

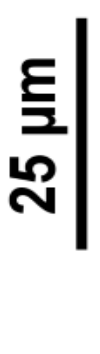

Figure 5- Phyllocoptes obtusus (Nalepa, 1891) a- Prodorsal shield, b- Genitalia

Material examined: İskele, Van (38 $\left.31^{\prime} 53 \mathrm{~N} ; 43^{\circ} 19^{\prime} 40 \mathrm{E} ; 1658 \mathrm{~m}\right) ; 28.06 .2015$ (5 우).

Host Plant: Salvia sp. (Lamiaceae)

Geographical distribution: Austria, Hungary, Russia, Yugoslavia (Amrine et al. 2003; Ripka, 2007) and Turkey (present study).

Remarks: This species is a vagrant on the undersurface of the leaves. There are approximately 900 species of Salvia genus in the world and 97 species exist in Turkey. Approximately 51 species of Salvia genus are endemic in Turkey (İpek \& Gürbüz, 2010). It is known that eriophyoid mites are host specific and show different symptoms according to the host species (Lindquist et al. 1996).

\section{Conclusions}

Eriophyoids are very important phytophagous pests on crops, herbaceous plants, grasses and shrubs, and they are mostly hostspecific or associated with a few hosts within a single genus or family. These mites have great potential for use as biological control agents of weeds because of their host specificity and their ability to significantly reduce the target weed's fitness (Smith et al. 2010). Knowledge of host plant specificity is necessary to develop effective control strategies and is fundamental in the application of the mites as biological control agents (Smith et al. 2010). To determine the host specificity of herbivores and to understand the role of each host species in the biology of the herbivore, information on the level of infestation of a pest on a particular host species is required (Skoracka \& Dabert, 2010; Skoracka \& Kuczyński, 2012).

In this study showed that, Aceria camdeboo, A. trifolii, Phyllocoptes obtusus, Aculus parakarensis and Leipothrix moraceus are recorded for the first time in Turkey. The influence these mites may have on the Turkish flora or their potential as weed control agents must still be determined. Future studies should continue focusing on eriophyoid mites as control agents of weeds, not ignoring their pest status.

\section{Acknowledgements}

The authors would like to thank Prof. Dr James W. Jr. Amrine (West Virginia University U.S.A) for confirmation of the new records. 


\section{References}

Amrine J W Jr \& Manson D C M (1996). "preparation, mounting and descriptive study of eriophyoid mites, 383-396". In: Eriophyoid Mite, Their Biology, Natural Enemies and Control (Eds: E.E. Lindquist, M.W. Sabelis \& J. Bruin. World Crop Pest, Elsevier, Amsterdam 787 pp.

Amrine J W Jr \& Stasny T A (1994). Catalog of the Eriophyoidea (Acarina: Prostigmata) of the World. Indira Publishing House, West Bloomfield, Michigan, USA 804 pp.

Amrine J W, Stasny T A \& Fletchmann C H W (2003). Revised Keys to the World Genera of the Eriophyoidea (Acari: Prostigmata). Indira Publishing House, West Bloomfield, Michigan 244 pp.

Bagdasarian AT (1972). Two new species of eriophyid mites on almond in Armenia (Acariformes, Eriophyoidea). Doklady Akademiya Nauk Armyanskiy SSR, 54: 190-191

Castagnoli M (1980). Gli acari Eriofidi del gelso in Italia con descripzione di Leipothrix moraceus sp. nov. Redia 63: 137-144

De Lillo E, Craemer C, Amrine J W \& Nuzzaci G (2010). Recommended procedures and techniques for morphological studies of Eriophyoidea (Acari: Prostigmata). Experimental Applied Acarology 51(3): 283-307. https://doi.org/10.1007/s10493-009-9311

Denizhan E (2018). Eriophyoid mites (Acari: Eriophyoidea) on fruit trees in Yalova, Turkey. Yüzüncü Yıl Üniversitesi Tarım Bilimleri Dergisi, 28(3): 285-288. https://doi.org/10.29133/yyutbd.398096

Denizhan E \& Cobanoğlu S (2010). Eriophyoid mites (Acari: Prostigmata: Erıophoidea) in Van Lake Basin from Turkey. International Journal of Acarology, 36(6): 503-510. https://doi.org/10.1080/01647954.2010.491486

Denizhan E, Monfreda R, Cobanoğlu S \& De Lillo E (2006). Three new Aceria species (Acari: Eriophyoidea) from Turkey. International Journal of Acarology, 32(2): 179-184. https://doi.org/10.1080/01647950608684458

Denizhan E, Monfreda R, De Lillo E \& Cobanoğlu S (2008). Two new species of the eriophyoid mites (Acari: Eriophyoidea) associated with Elaeagnaceae in Turkey. Zootaxa, 1698 (2): 41-48. https://doi.org/10.5281/zenodo.180758

Denizhan E, R Monfreda, E De Lillo \& Cobanoğlu S (2015). Eriophyoid mite fauna (Acari: Trombidiformes: Eriophyoidea) of Turkey: new species, new distribution reports and an updated catalogue. Zootaxa, 3991(1): 1-63. http://dx.doi.org/10.11646/zootaxa.3991.1.1

Diler H \& Ozman-Sullivan S K (2011). " Eriophyoid Mites on Weeds in Hazelnut Orchards". Proceedings of the Fourth Plant Protection Congress of Turkey (28-30 June 2011, Kahramanmaraş,-Turkey), 309 s.

Diler H \& Ozman-Sullivan S K (2016). "Eriophyoid mites and their population densities on weeds of the family Asteraceae in wheat fields in the central Anatolian region of Turkey". $6^{\text {th }}$ Plant Protection Congress with International Participation (5-8 September 2016, Konya, Turkey), $442 \mathrm{~s}$.

Ekim T \& Güner A (2000). Introduction: The floristic richness of Turkey. Curtis's Botanical Magazine, 17(2): 48-59

Gokce M P, Karagoz M, Faraji F \& Cakmak I (2020). Mite species composition and their population densities on chestnut trees in Turkey. International Journal of Acarology, 46(4): 247-253. https://doi.org/10.1080/01647954.2020.1752796

İpek A \& Gürbüz B (2010). Salvia species in flora of Turkey and their status in danger. Tarla Bitkileri Merkez Araştırma Enstitüsü Dergisi 19(1-2): 30-35

Keifer H H (1975). "Injurious Eriophyoid Mites, 327-533". In: Mites Injurious to Economic Plants (Eds: L.R. Jeppson, H.H. Keifer \& E.W. Baker). University of California Press, Berkeley, CA, $614 \mathrm{pp.}$

Karagöz A (2003). Plant genetic resources conservation in Turkey. Acta Horticulturae, 598(2): 17-25. https://doi.org/10.17660/ActaHortic. 2003.598.1

Lindquist E E, Sabelis M W \& Bruin J (1996). Eriophyoid Mites, Their Biology, Natural Enemies and Control. World Crop Pest, Elsevier, Amsterdam, $787 \mathrm{pp}$.

Meyer M K P (Smith) (1981). South African Eriophyidae (Acari): The Genus Aceria Keifer, 1944. Phytophylactica (13): 117-126

Ripka G (2007). Checklist of the eriophyoid mite fauna of Hungary (Acari: Prostigmata: Eriophyoidea). Acta Phytopathologica et Entomologica Hungarica 42(1): 59-142. DOI: 10.1556/APhyt.42.2007.1.7

Skoracka A \& Dabert M (2010). The cereal rust mite Abacarus hystrix (Acari: Eriophyoidea) is a complex of species: evidence from mitochondrial and nuclear DNA sequences. Bulletin of Entomological Research, 100(3): 263-272. https://doi.org/10.1017/S0007485309990216

Skoracka A \& Kuczyński L (2012). Measuring the host specificity of plant-feeding mites based on field data - a case study of the Aceria species. Biologia 67(3): 546-560. DOI: 10.2478/s11756-012-0025-x

Smith L, De Lillo E \& Amrine J W (2010). Effectiveness of eriophyid mites for biological control of weedy plants and challenges for future research. Experimental and Applied Acarology, 51(1): 115-149. DOI: 10.1007/s10493-009-9299-2

Usanmaz H, Karadağ S \& Denizhan E (2018). First record for the Turkish mite fauna; Aceria stefanii (Nalepa, 1898) (Acariformes: Eriophyidae). Plant Protection Bulletin, 58(3): 195-198. https://doi.org/10.16955/bitkorb.372691

Wang Z, Han X \& Hong X Y (2017). Three new species of Leipothrix Keifer (Acari: Eriophyidae) from China. Systematic \& Applied Acarology, 22(12): 2023-2037. http://doi.org/10.11158/saa.22.12.1

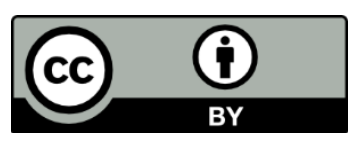

(C) 2022 by the author(s). Published by Ankara University, Faculty of Agriculture, Ankara, Turkey. This is an Open Access article distributed under the terms and conditions of the Creative Commons Attribution (CC BY) license (http://creativecommons.org/licenses/by/4.0/), which permits unrestricted use, distribution, and reproduction in any medium, provided the original work is properly cited. 